\section{TINGKAT KETAHANAN MASYARAKAT TERHADAP BENCANA KEKERINGAN DI KELURAHAN ROWOSARI, KOTA SEMARANG}

\author{
Fajar Kurnia Sakti, , Holi Bina Wijaya \\ Departemen Perencanaan Wilayah dan Kota, Fakultas Teknik, \\ Universitas Diponegoro, Semarang, Indonesia
}

\author{
Jurnal Pengembangan Kota (2020) \\ Volume 8 No. 1 (100-108) \\ Tersedia online di: \\ http://ejournal2.undip.ac.id/index.php/jpk \\ DOI: 10.14710/jpk.8.1.100-108
}

\begin{abstract}
Abstrak. Penilaian Tingkat Ketahanan Masyarakat merupakan langkah awal menuju peningkatan ketahanan dan membuat pemangku kepentingan untuk memprioritaskan tindakan yang diperlukan dalam menangani suatu kondisi masyarakat yang mengalami tekanan dan guncangan. Kelurahan Rowosari merupakan salah satu wilayah yang terdampak bencana kekeringan setiap tahunnya. Bencana kekeringan yang terjadi berimbas pada penurunan debit air bersih yang digunakan untuk memenuhi kebutuhan konsumsi masyarakat. Berdasarkan kondisi tersebut menimbulkan pertanyaan seperti "Seperti apa tingkat ketahanan masyarakat terhadap bencana kekeringan di Kelurahan Rowosari?". Digunakan metode kuantitatif untuk menjabarkan hasil penelitian. Analisis deskriptif kuantitatif digunakan untuk menunjukan kondisi eksisting masyarakat yang terdiri dari aspek fisik, sosial, ekonomi dan kelembagaan. Teknik analisis skoring menggunakan metode Sturges yang digunakan sebagai alat untuk melakukan pengukuran terhadap tingkat ketahanan masyarakat. Hasil Tingkat ketahanan masyarakat Kelurahan Rowosari terhadap bencana kekeringan menunjukan skor akhir sebesar 2,00 dan termasuk dalam tingkat ketahanan menengah. Pada tingkatan tersebut masih perlu dilakukan peningkatan dari berbagai aspek, hal ini dikarenakan pada tingkat tersebut juga rawan terjadi penurunan akibat kurangnya kepedulian masyarakat untuk menghadapi bencana kekeringan.
\end{abstract}

Kata Kunci: Bencana Kekeringan; Ketahanan; Tingkat Ketahanan Masyarakat; Kelurahan Rowosari

[Title: Community Resilience to drought disaster in Rowosari Village, Semarang City]. Assessment of Community Resilience Levels is the first step towards increasing resilience and making stakeholders prioritize the actions needed in dealing with a community condition that is experiencing pressure and shocks. Rowosari Urban Village is one of the areas affected by drought every year. The drought that occurred has an impact on the reduction in the flow of clean water that is used to meet people's consumption needs. Based on these conditions raises questions such as "What is the level of resilience of the community against drought in Rowosari Urban Village?". Quantitative methods are used to describe the results of research. Quantitative descriptive analysis is used to show the condition of the existing community which consists of physical, social, economic, and institutional aspects. The scoring analysis technique uses the Sturges method which is used as a tool to measure the level of community resilience. Results The level of resilience of the Rowosari Urban Village community to drought shows a final score of 2.00 and is included in the medium resilience level. At this level, it still needs to be improved from various aspects, this is because at that level it is also prone to a decline due to the lack of community awareness to deal with drought.

Keyword: Drought Disaster; Resilience; Community Resilience Level; Rowosari Urban Village

Cara Mengutip: Sakti, F. K., \& Wijaya, H. B. (2019). Tingkat Ketahanan Masyarakat Terhadap Bencana Kekeringan di Kelurahan Rowosari, Kota Semarang. Jurnal Pengembangan Kota. Vol 8 (1): 100-108. DOI: 10.14710/jpk.8.1.100-108

\section{PENDAHULUAN}

Kekeringan merupakan fenomena yang kompleks dan umumnya terjadi karena berkurangnya ketersediaan air tanah dalam jangka waktu tertentu. Selain itu kekeringan merupakan sebuah fenomena yang berulang dan dapat mempengaruhi semua wilayah geografis, akan tetapi daerah yang akan memiliki dampak terparah adalah daerah yang termasuk daerah semi gersang atau gersang dan sangat dipengaruhi oleh intensitas curah hujan (Thomas, Jaiswal, Galkate, \& Nayak, 2016). Besarnya kerugian yang muncul akibat terjadinya kekeringan menjadikan 
fenomena kekeringan kedalam kategori bencana. Durasi musim yang tidak menentu tersebut erat kaitannya dengan terjadinya perubahan iklim global. Perubahan iklim global selama beberapa tahun terakhir memberikan dampak nyata berupa perubahan durasi cuaca yang berimbas pada terjadinya bencana kekeringan (McMichael, Campbell-Lendrum, Corvalán, Ebi, Githeko, Scheraga, \& Woodward, 2003).

Terjadinya perubahan iklim global secara tidak langsung mendorong masyarakat untuk menyesuaikan keadaan pada beberapa aspek kehidupan. Upaya penyesuaian atau adaptasi tersebut merupakan bentuk respon ketahanan suatu sistem sosial dalam menghadapi tekanan dan guncangan. Beberapa penelitian mengenai ketahanan komunitas dalam menghadapi suatu bencana rata-rata menunjukan penilaian terhadap aspek-aspek yang mempengaruhi kehidupan. Berdasarkan hal tersebut, penelitian ini bertujuan untuk merancang penilaian dan mengetahui gambaran ketahanan komunitas dalam menghadapi bencana kekeringan.

Kelurahan Rowosari merupakan salah satu wilayah yang terdampak bencana kekeringan paling parah di Kota Semarang. Parahnya kondisi tersebut ditunjukan pada tingginya masyarakat yang terdampak bencana kekeringan hingga menyentuh angka 200 KK (Prabowo, 2014). Bencana kekeringan yang melanda Kelurahan Rowosari menimbulkan kerugian berupa kekurangan sumber daya air untuk konsumsi sehari-hari yang biasa digunakan oleh masyarakat akibat musim kemarau berkepanjangan. Besarnya dampak bencana kekeringan yang menerpa Kelurahan Rowosari tidak terlepas dari kondisi air tanah (hidrogeologi) yang terdapat di daerah tersebut. Berdasarkan data Bappeda Kota Semarang tahun 2011, sebaran sumber air tanah di Kelurahan Rowosari didominasi oleh sumber air tanah langka dengan luasan sekitar 50\% dari luas daerah total (Bappeda Kota Semarang, 2011). Kemudian wilayah Kelurahan Rowosari juga didominasi oleh kondisi intensitas curah hujan yang tergolong sedang sekitar 27,7-34,8 mm/tahun. Sehingga dengan adanya kondisi tersebut menjadikan daerah tersebut menjadi sangat rentan terjadi bencana kekeringan saat musim kemarau. Berdasarkan pernyataan Adiwicaksono, Sudarto, dan Widianto
(2014), periode El Nino yang terjadi akibat dampak adanya perubahan iklim global juga dapat mempengaruhi durasi musim kemarau.

Terdapat tiga wilayah RW dari 9 RW yang terdapat di Kelurahan Rowosari merupakan daerah yang selalu dilanda bencana kekeringan saat musim kemarau tiba. Kerugian yang ditanggung oleh masyarakat kebanyakan berupa kurangnya pasokan air bersih untuk memenuhi kebutuhan sehari-hari. Berdasarkan pemaparan Prabowo (2014), tercatat pada tahun 2014 sebanyak 200 KK di RW 6 terdampak bencana kekeringan. Kemudian bencana kekeringan juga melanda RW 9 pada tahun 2018. Sedangkan RW 1 juga merupakan salah satu daerah yang terdampak bencana kekeringan pada tahun 2016.

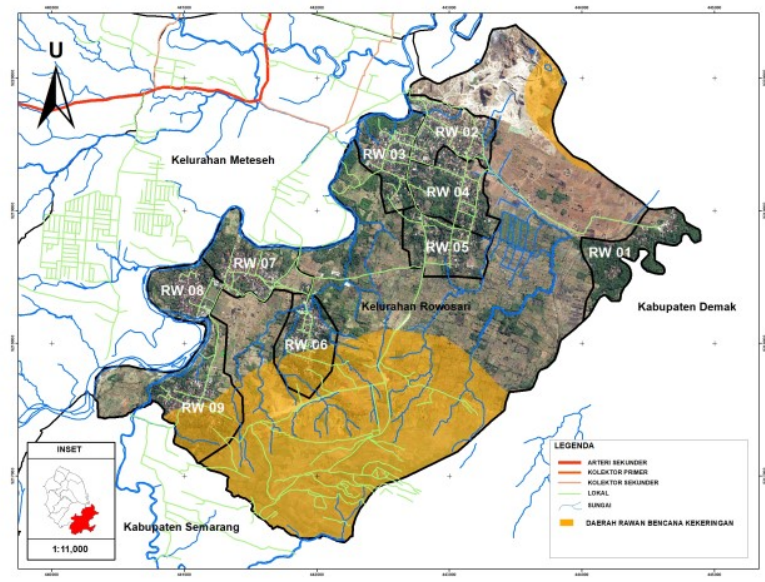

Gambar 1. Peta Rawan Bencana Kekeringan di Kelurahan Rowosari

Salah satu konsep yang digunakan untuk menjawab tantangan perubahan iklim global adalah konsep ketahanan. Konsep tersebut menjelaskan kemampuan sistem untuk mengantisipasi, mengurangi, mengatasi dampak dan memulihkannya dari kondisi yang sulit tanpa merugikan perencanaan yang telah disusun dalam jangka panjang (Bolte, Orlowsky, Marr, Moore, Rahmadana, \& Sitompul, 2017). Terdapat beberapa sudut pandang dalam memahami suatu

ISSN 2337-7062 (c) 2020

This is an open access article under the CC-BY-NC-ND license (http://creativecommons.org/licenses/by-nc-sa/4.0/). - lihat halaman depan (C) 2020

*Email fajarkurnias02@gmail.com

Diterima 12 Desember 2019, disetujui 15 Juni 2020 
konsep ketahanan, salah satunya adalah ketahanan komunitas. Ketahanan dalam sudut komunitas berfokus pada kapasitas masyarakat dalam menghadapi tekanan dan guncangan. Terdapat beberapa aspek pendukung dalam membentuk ketahanan komunitas yaitu berupa aspek fisik, sosial, ekonomi dan kelembagaan (Kabir, Sato, Habbiba, \& Yousuf, 2018). Aspekaspek tersebut juga dapat digunakan sebagai tolak ukur tingkat ketahanan yang terdapat disuatu daerah. Sehingga dengan dilakukannya penilaian terhadap ketahanan komunitas, dapat mendorong komunitas agar dapat meningkatkan kapasitas dalam menghadapi tekanan dan guncangan yang melanda suatu daerah.

\section{METODE PENELITIAN}

Penelitian ini menggunakan metode analisis deskriptif kuantitatif yang berlandaskan pada datadata numerik atau angka yang diolah dengan metode statistik. Tujuan penelitian kuantitatif yaitu digunakan untuk meneliti pada populasi atau sampel tertentu yang representatif, untuk mengumpulkan data menggunakan instrumen penelitian, analisis data bersifat kuantitatif/statistik. Secara umum, penelitian kuantitatif ini dilakukan pada sampel yang diambil secara random, sehingga kesimpulan dari hasil penelitian dapat digeneralisasikan pada populasi dimana sampel diambil (Sugiyono, 2012).

Analisis yang dilakukan selanjutnya adalah analisis skoring dengan cara memberikan skor terhadap indikator yang digunakan dalam penelitian. Kategori yang digunakan dalam skoring ini ditentukan melalui tiga kelas yaitu tinggi, menengah dan rendah. Tiga kelas kategori tesebut didapatkan melalui perhitungan menggunakan rumus Sturges.

Tabel 1.

Interval Skor Tingkat Ketahanan Komunitas

\begin{tabular}{cc}
\hline Skoring Indikator & Keterangan \\
\hline $1,00-1,70$ & Tingkat Ketahanan Rendah \\
\hline$>1,70-\leq 2,30$ & $\begin{array}{c}\text { Tingkat Ketahanan } \\
\text { Menengah }\end{array}$ \\
\hline$>2,30-3,00$ & Tingkat Ketahanan Tinggi \\
\hline
\end{tabular}

Adapun indikator yang digunakan untuk analisis skoring tingkat ketahanan masyarakat Kelurahan Rowosari sebagai berikut.

Tabel 2.

Variabel dan Indikator Penelitian

\begin{tabular}{|c|c|c|}
\hline Variabel & Indikator & Sumber \\
\hline \multirow{7}{*}{ Fisik } & $\begin{array}{l}\text { Kepemilikan } \\
\text { sumur gali }\end{array}$ & \multirow{7}{*}{$\begin{array}{l}\text { UK Government } \\
\qquad(2011)\end{array}$} \\
\hline & $\begin{array}{l}\text { Kepemilikan } \\
\text { jaringan air bersih } \\
\text { PDAM }\end{array}$ & \\
\hline & $\begin{array}{l}\text { Kepemilikan } \\
\text { sumber air } \\
\text { alternatif }\end{array}$ & \\
\hline & $\begin{array}{l}\text { Tingkat konsumsi } \\
\text { air bersih }\end{array}$ & \\
\hline & $\begin{array}{l}\text { Kondisi jaringan } \\
\text { jalan }\end{array}$ & \\
\hline & $\begin{array}{l}\text { Sarana } \\
\text { transportasi }\end{array}$ & \\
\hline & Fasilitas kesehatan & \\
\hline \multirow{4}{*}{ Sosial } & Kegiatan sosial & \multirow{4}{*}{$\begin{array}{c}\text { Maguire dan } \\
\text { Hagan (2007) \& } \\
\text { Rigg, Salamanca, } \\
\text { dan Parnwell } \\
\text { (2012) }\end{array}$} \\
\hline & Kapasitas SDM & \\
\hline & Kepemimpinan & \\
\hline & $\begin{array}{l}\text { Pengetahuan } \\
\text { terhadap bencana }\end{array}$ & \\
\hline \multirow{4}{*}{ Ekonomi } & $\begin{array}{l}\text { Tingkat } \\
\text { pendapatan } \\
\text { keluarga }\end{array}$ & \multirow{4}{*}{$\begin{array}{c}\text { Rangwala, Elias- } \\
\text { trostmann, } \\
\text { Wihanesta, } \\
\text { Chandra, dan Org } \\
\text { (2018) \& Sina, } \\
\text { Chang-richards, } \\
\text { Wilkinson, dan } \\
\text { Potangaroa (2019) }\end{array}$} \\
\hline & $\begin{array}{l}\text { Kepemilikan } \\
\text { pekerjaan tetap }\end{array}$ & \\
\hline & $\begin{array}{l}\text { Kepemilikan } \\
\text { tabungan }\end{array}$ & \\
\hline & $\begin{array}{l}\text { Kepemilikan } \\
\text { asuransi }\end{array}$ & \\
\hline \multirow{3}{*}{ Kelembagaan } & $\begin{array}{l}\text { Kerja sama } \\
\text { masyarakat } \\
\text { dengan lembaga }\end{array}$ & \multirow{3}{*}{ Bolte dkk. (2017) } \\
\hline & $\begin{array}{l}\text { Bantuan yang } \\
\text { didapatkan dari } \\
\text { lembaga }\end{array}$ & \\
\hline & Edukasi & \\
\hline
\end{tabular}

Penelitian ini menggunakan purposive sampling yang merupakan teknik sampling dengan suatu pertimbangan tertentu. Pertimbangan pada sampel bahwa sampel memiliki hubungan yang erat terhadap populasi sehingga dapat merepresentasikan dengan tepat. Purposive sampling dilakukan dengan memilih orang sebagai sampel yang memiliki ciri-ciri tertentu sesuai dengan yang telah ditetapkan. Oleh karena itu, 
responden yang menjadi sasaran penelitian memiliki kriteria sebagai berikut:

a) Merupakan perwakilan dari KK yang bertempat tinggal di RW 01, RW 06 \& RW 09 Kelurahan Rowosari

b) Berusia antara 15-64 tahun

Sesuai dengan metode pengambilan sampel tersebut, penentuan jumlah responden didasarkan pada jumlah KK di RW 01, RW 06 \& RW 09 Kelurahan Rowosari. Jumlah penduduk yang terdapat di RW tersebut pada tahun 2019 adalah 650 KK. Sehingga pengambilan sampel berdasarkan rumus Slovin didapatkan hasil 87 responden dan kemudian dilakukan proporsi dalam distribusi sampel sebagai berikut.

Tabel 3.

Proporsi Sampel Tiap RW

\begin{tabular}{ccc}
\hline RW & Jumlah KK & Jumlah Sampel \\
\hline 01 & 103 & 15 \\
\hline 06 & 258 & 35 \\
\hline 09 & 289 & 37 \\
\hline
\end{tabular}

\section{HASIL DAN PEMBAHASAN}

\section{Analisis Tingkat Ketahanan Fisik}

Analisis tingkat ketahanan fisik menilai tentang kondisi sarana dan prasarana seperti ketersediaan air bersih, kemudahan aksesibilitas dan jangkauan fasilitas kesehatan. Pada masing-masing indikator tersebut dilakukan identifikasi yang selanjutnya akan dilanjutkan dengan proses analisis skoring dengan hasil akhir sebagai berikut.

Tabel 4.

Skoring Tingkat Ketahanan Fisik Kelurahan Rowosari

\begin{tabular}{|c|c|}
\hline Indikator & Skor Akhir \\
\hline Ketersediaan Air Bersih & 2,19 \\
\hline Kepemilikan sumur gali & 1,71 \\
\hline $\begin{array}{l}\text { Kepemilikan jaringan air } \\
\text { bersih PDAM }\end{array}$ & 1,30 \\
\hline $\begin{array}{l}\text { Kepemilikan sumber air } \\
\text { alternatif }\end{array}$ & 2,75 \\
\hline $\begin{array}{l}\text { Tingkat konsumsi air } \\
\text { bersih }\end{array}$ & 3,00 \\
\hline Kemudahan Aksesibilitas & 2,35 \\
\hline Kondisi jaringan jalan & 2,71 \\
\hline Sarana transportasi & 2,00 \\
\hline Jangkauan Fasilitas Kesehatan & 1,12 \\
\hline Tingkat Ketahanan Fisik & 1,88 \\
\hline
\end{tabular}

Berdasarkan perhitungan tersebut indikator kemudahan aksesibilitas menunjukan kondisi yang terbaik dengan skor akhir sebesar 2,35. Hal ini didukung dengan hampir meratanya pembangunan jalan di wilayah Kelurahan Rowosari. Selain memudahkan pergerakan manusia, meratanya pembangunan jalan juga dapat memudahkan pihak-pihak pemberi bantuan pasokan air bersih saat terjadinya bencana kekeringan. Kemudian untuk kategori terendah yaitu jangkauan fasilitas kesehatan dengan skor akhir sebesar 1,12. Rendahnya nilai tersebut dikarenakan letak wilayah RW 01 dan RW 09 yang relatif melebihi batas maksimum standar pelayanan Puskesmas. Namun hal tersebut mampu ditanggulangi dengan tersedianya kemudahan aksesibilitas berupa penyediaan jalan yang sudah cukup baik dan dilengkapi dengan kendaraan pribadi yang dimiliki oleh setiap masyarakat.

Terakhir adalah indikator ketersediaan air bersih yang masuk dalam kategori menengah dengan skor akhir sebesar 2,19. Ketersediaan air bersih di Kelurahan Rowosari berdasarkan respon masyarakat dapat dikatakan mencukupi, namun apabila dilihat dari segi perawatan dan pemeliharaan masih perlu ditingkatkan. Hasil perhitungan akhir skoring untuk ketahanan fisik Kelurahan Rowosari menunjukan skor akhir sebesar 1,88 dan masuk dalam kategori menengah. Maka dari itu dengan tersedianya sarana dan prasarana yang mudah diakses oleh masyarakat dapat meningkatkan resistansi terhadap bencana kekeringan yang ada di Kelurahan Rowosari. Selain itu juga diperlukan kegiatan pemantauan dan pemeliharaan untuk menjaga maupun meningkatkan kualitas sarana dan prasarana agar mampu mengatasi dampak dari ketidakpastian iklim dan mengurangi kerugian yang dihasilkan setelahnya (UK Government, 2011).

\section{Analisis Tingkat Ketahanan Sosial}

Proses analisis tingkat ketahanan sosial, mendalami tentang modal sosial yang dimiliki oleh masyarakat Kelurahan Rowosari. Modal sosial tersebut dapat diketahui dari kegiatan sosial yang terdapat di lingkungan masyarakat, kapasitas sumber daya manusia (SDM), kepemimpinan yang terdapat di lingkungan masyarakat dan tingkat pengetahuan masyarakat terhadap tekanan. 
Tabel 5.

Skoring Tingkat Ketahanan Sosial Kelurahan Rowosari

\begin{tabular}{lc}
\hline Indikator & Skor Akhir \\
\hline Kegiatan sosial & 1,00 \\
\hline Kapasitas SDM & 1,21 \\
\hline Kepemimpinan & 2,95 \\
\hline Pengetahuan terhadap bencana & 2,34 \\
\hline Tingkat Ketahanan Sosial & $\mathbf{1 , 8 7}$ \\
\hline
\end{tabular}

Dari perhitungan tersebut didapatkan skor akhir sebesar 1,87 dan termasuk dalam kategori menengah. Kondisi tersebut dapat disimpulkan secara keseluruhan modal sosial yang dimiliki masyarakat Kelurahan Rowosari terhitung masih rentan. Hal ini dapat diketahui hanya terdapat dua indikator dari empat indikator pembangun ketahanan sosial yang tergolong dalam tingkat ketahanan tinggi yaitu kepemimpinan dan pengetahuan masyarakat terhadap tekanan. Akan tetapi pada indikator pengetahuan masyarakat dalam menghadapi bencana kekeringan masih terdapat kekurangan seperti masyarakat hanya melakukan penanganan hanya saat terjadi bencana, untuk kegiatan sebelum dan setelah bencana tidak dilakukan kegiatan preventif untuk menangani bencana kekeringan. Masyarakat hanya mengandalkan bantuan dari lembaga terkait untuk penyediaan air bersih baik berupa dropping air bersih, pembangunan sumur artesis dan pembuatan toren penampungan air bersih. Selain itu rendahnya kapasitas SDM dapat menunjukan kapasitas pemahaman masyarakat dalam melakukan kegiatan preventif dalam penyediaan kebutuhan air saat bencana kekeringan terjadi. Indikator kegiatan sosial yang berfokus pada kegiatan masyarakat dalam mengatasi bencana kekeringan juga tergolong dalam kondisi yang rendah. Hal ini dikarenakan belum terdapatnya kesadaran masyarakat untuk menciptakan atau membentuk kelompok untuk menangani dan memberikan bekal secara mandiri kepada masyarakat di lingkungan mereka sendiri.

\section{Analisis Tingkat Ketahanan Ekonomi}

Akses ke sumber daya keuangan dapat meningkatkan ketersediaan opsi ketahanan masyarakat dan dapat memudahkan dapat menentukan keputusan untuk memenuhi kebutuhan hidupnya (Rangwala dkk., 2018). Untuk mengetahui kondisi ketahanan ekonomi masyarakat Kelurahan Rowosari menggunakan indikator diantaranya seperti pendapatan masyarakat yang dijabarkan menjadi tingkat pendapatan keluarga dan kepemilikan pekerjaan tetap. Kemudian indikator tabungan yang dijabarkan menjadi kepemilikan tabungan dan kepemilikan asuransi.

Tabel 6.

Skoring Tingkat Ketahanan Ekonomi Kelurahan Rowosari

\begin{tabular}{|c|c|c|}
\hline Indikator & & Skor Akhir \\
\hline \multirow[t]{3}{*}{ Pendapatan } & & 1,54 \\
\hline & $\begin{array}{l}\text { Tingkat pendapatan } \\
\text { keluarga }\end{array}$ & 1,43 \\
\hline & $\begin{array}{l}\text { Kepemilikan pekerjaan } \\
\text { tetap }\end{array}$ & 1,65 \\
\hline \multirow[t]{3}{*}{ Tabungan } & & 2,23 \\
\hline & Kepemilikan tabungan & 1,51 \\
\hline & Kepemilikan asuransi & 2,95 \\
\hline Tingkat Ketal & anan Ekonomi & 1,88 \\
\hline
\end{tabular}

Aspek ekonomi merupakan perangkat dasar dalam terciptanya kehidupan rumah tangga hingga masyarakat. Hal ini dikarenakan masyarakat yang memiliki kondisi ekonomi tercukupi mampu menciptakan kesejahteraan dan meningkatkan ketahanan dari tekanan dan guncangan yang melanda lingkungan tempat tinggal mereka sendiri. Berdasarkan perhitungan skoring untuk seluruh indikator ketahanan ekonomi didapatkan skor akhir sebesar 1,88 dan termasuk dalam kategori tingkat menengah. Dapat diketahui bahwa terdapat indikator yang tergolong dalam kategori rendah yaitu indikator pendapatan. Rendahnya indikator pendapatan pada masyarakat Kelurahan Rowosari dipengaruhi oleh banyak terdapat masyarakat yang memiliki pekerjaan tetap namun berpenghasilan tidak tetap sehingga berpengaruh terhadap tidak menentunya pemasukan keuangan untuk memenuhi kebutuhan rumah tangga masing-masing. Sehingga hal tersebut menyebabkan masyarakat Kelurahan Rowosari belum mampu secara mandiri dalam melakukan langkah pereventif dalam menangani bencana kekeringan, dikarenakan faktor ekonomi yang hanya fokus digunakan melengkapi kebutuhan sehari-hari. Namun kondisi tersebut dapat dibantu dengan terdapatnya akses terhadap subsidi masyarakat kepada lembaga pemerintah ditemui banyak masyarakat Kelurahan Rowosari yang 
memperoleh hal tersebut dalam bentuk sembako, beras dan uang. Mudahnya masyarakat dalam mengakses subsidi tersebut merupakan salah satu keberhasilan subsidi sebagai alat penguatan ketahanan masyarakat. Akan tetapi rata-rata subsidi yang diberikan hanya kepada masyarakat yang berpenghasilan rendah, namun belum semua masyarakat yang dianggap sebagai masyarakat berpenghasilan rendah juga tidak bisa mengakses subsidi tersebut.

Kemudian terdapat indikator lainnya yang termasuk dalam kategori menengah, yaitu tabungan. Untuk pengelolaan keuangan dalam skala rumah tangga, masyarakat Kelurahan Rowosari masih ditemukan banyak masyarakat yang tidak memiliki tabungan, hal ini berkebalikan dengan kepemilikan asuransi kesehatan dalam bentuk investasi kesehatan yang rata-rata masyarakat memiliki. Kondisi tersebut membuat masyarakat rentan untuk memenuhi kebutuhan ketika terjadi suatu tekanan atau guncangan seperti bencana kekeringan. Sehingga, berdasarkan hasil masing-masing indikator tersebut menunjukan kondisi masyarakat Kelurahan Rowosari dalam ketahanan ekonomi masih berada dikondisi yang tidak aman dalam mempersiapkan kebutuhan menghadapi bencana kekeringan dan dibutuhkan pihak eksternal dalam rangka penyelenggaraan kegiatan untuk mengatasi dan mengantisipasi bencana kekeringan.

\section{Analisis Tingkat Ketahanan Kelembagaan}

Terbentuknnya kerja sama dengan pihak eksternal sangat penting dilakukan oleh masyarakat, hal tersebut dilakukan agar ketahanan komunitas menjadi jelas berkat adanya dukungan dari pihak eksternal. Dalam melakukan proses analisis terkait ketahanan kelembagaan menggunakan indikator kolaborasi lembaga dan edukasi.

Tabel 7.

Skoring Tingkat Ketahanan Kelembagaan Kelurahan Rowosari

\begin{tabular}{llc}
\hline \multicolumn{1}{l}{ Indikator } & Skor Akhir \\
\hline \multicolumn{2}{l}{ Kolaborasi Lembaga } & $\mathbf{2 , 3 2}$ \\
\hline $\begin{array}{l}\text { Kerja sama masyarakat } \\
\text { dengan lembaga } \\
\text { Bantuan yang } \\
\text { didapatkan dari lembaga }\end{array}$ & 2,35 \\
\hline Edukasi & 2,29 \\
\hline \multicolumn{2}{l}{ Tingkat Ketahanan Kelembagaan } & $\mathbf{2 , 4 7}$ \\
\hline
\end{tabular}

Hasil penilaian skoring yang telah dilakukan pada tingkat ketahanan kelembagaan di Kelurahan Rowosari, mendapatkan skor akhir sebesar 2,39, dan masuk dalam kategori tinggi. Pada kedua indikator yang digunakan seperti kolaborasi lembaga dan edukasi memberikan hasil yang berdampak baik pada peningkatan modal untuk masyarakat dalam menghadapi bencana kekeringan. Hal tersebut terbentuk karena pada dasarnya dengan kuatnya suatu komunitas dalam menjalin hubungan dengan pihak eksternal akan mampu memberi kejelasan nyata dalam mewujudkan ketahanan yang terdapat di dalam lingkungan masyarakat itu sendiri (Bolte dkk., 2017).

Indikator kolaborasi lembaga yang terdapat di Kelurahan Rowosari diketahui sudah banyak menjalin hubungan dengan lembaga eksternal dalam hal penanganan bencana kekeringan. Hasil dari kerja sama tersebut berbentuk fisik untuk pemenuhan kebutuhan air bersih masyarakat Kelurahan Rowosari. Namun penyediaan sumber air tersebut tidak diimbangi dengan pengelolaan dan pemeliharaan yang cukup baik. Kemudian terdapat indikator edukasi yang disediakan oleh pihak eksternal kepada masyarakat Kelurahan Rowosari yang sudah dilakukan dan didorong oleh antusias masyarakat yang baik. Edukasi yang diberikan kepada masyarakat berupa penyuluhan seperti langkah penghematan air bersih oleh pihak unversitas dan pemerintah, serta juga terdapat kegiatan penyuluhan mengurangi dampak bencana kekeringan dengan menjaga lingkungan sekitar tetap lestari. Untuk hasil penyuluhan tersebut masih banyak terdapat masyarakat yang belum mampu menerapkannya dalam hal penghematan air, karena ketersediaan air bersih yang sangat minim ketika bencana kekeringan tiba.

\section{Analisis Tingkat Ketahanan Masyarakat Kelurahan Rowosari}

Penilaian tingkat ketahanan komunitas akan berfokus pada masyarakat Kelurahan Rowosari yang tinggal di RW 01, RW 06 dan RW 09 yang memiliki karakteristik serupa terkait terjadinya bencana kekeringan. Dalam penyajian pembahasan tentang tingkat ketahanan masyarakat Kelurahan Rowosari akan mencakup tentang aspek fisik, sosial, ekonomi dan lembaga. Berdasarkan analisis yang telah dilakukan dari 
keempat aspek tersebut, dapat menunujukan penilaian akhir terkait tingkat ketahanan masyarakat Kelurahan Rowosari melalui perhitungan skoring rata-rata dari setiap aspek yang dijadikan variabel penelitian.

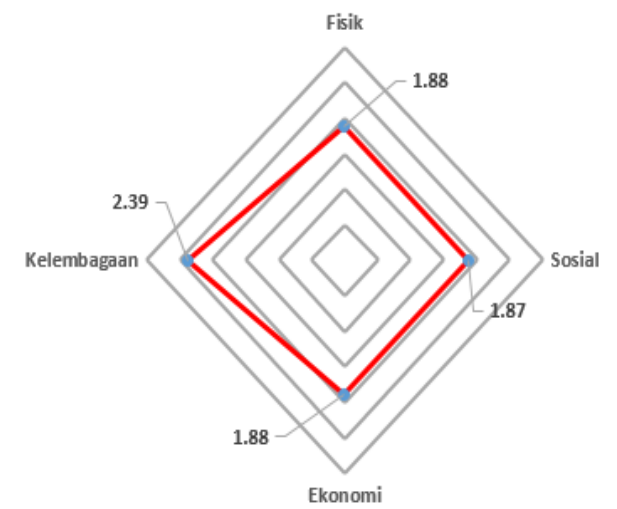

Gambar 2. Hasil Skoring Variabel Tingkat Ketahanan Masyarakat di Kelurahan Rowosari

Berdasarkan analisis yang telah dilakukan pada keseluruhan aspek, didapatkan temuan penelitian tingkat ketahanan masyarakat Kelurahan Rowosari berada dalam tingkat menengah dengan menghasilkan skor akhir sebesar 2. Meskipun tergolong dalam tingkat menengah, pada titik tersebut masih perlu dilakukan peningkatan dari berbagai aspek. Hal ini dikarenakan pada tingkat tersebut juga rawan terjadi penurunan akibat kurangnya kepedulian masyarakat untuk menghadapi bencana kekeringan dan juga setelah dilakukan analisis dari setiap aspek, kebanyakan menunjukan bahwa masyarakat belum mampu secara mandiri mengatasi bencana kekeringan.

Mengacu pada literatur yang digunakan oleh peneliti tentang tingkat ketananan komunitas Bahadur, Ibrahim, \& Tanner (2010); Kabir dkk., (2018); Mayunga (2007), mewujudkan ketahanan di tingkat masyarakat pada dasarnya dibutuhkan partisipasi masyarakat dalam menciptakan kebijakan dan konseptualisasi ketahanan yang disesuaikan dengan kapasitas masyarakat sebagai objek yang diteliti. Berdasarkan pemahaman tersebut memunculkan sebuah cara dalam menciptakan ketahanan masyarakat dalam menghadapi bencana melalui komponenkomponen yang terdapat dalam masyarakat (sistem). Komponen - komponen tersebut berupa aspek fisik, aspek sosial, aspek ekonomi, aspek kelembagaan dan aspek alam yang dipandang sebagai faktor penentu ketahanan. Hasil penelitian tentang tingkat ketahanan masyarakat terhadap bencana kekeringan di Kelurahan Rowosari menunjukan bahwa, terbentuk kesinambungan antara aspek-aspek yang digunakan dalam penelitian dengan literatur konsep yang digunakan sebagai acuan. Hal ini dapat diketahui dari ditemuinya tiga aspek dengan tingkat ketahanan menengah seperti aspek fisik, aspek sosial dan aspek ekonomi, dapat ditingkatkan melalui variabel dengan hasil tingkat ketahanan tinggi seperti aspek kelembagaan. Sehingga secara keseluruhan masyarakat secara tidak langsung masih sangat bergantung pada pihak eksternal untuk menciptakan ketahanan di lingkungan Kelurahan Rowosari. Kemudian dalam penelitian ini, aspek alam tidak digunakan karena dianggap lebih cenderung menjadi ancaman seperti bencana kekeringan dan kondisi fisik alam yang terdapat di Kelurahan Rowosari rata-rata didominasi oleh daerah air tanah langka. Sehingga hasil akhir dari penelitian dapat diketahui dari bagan dibawah ini.

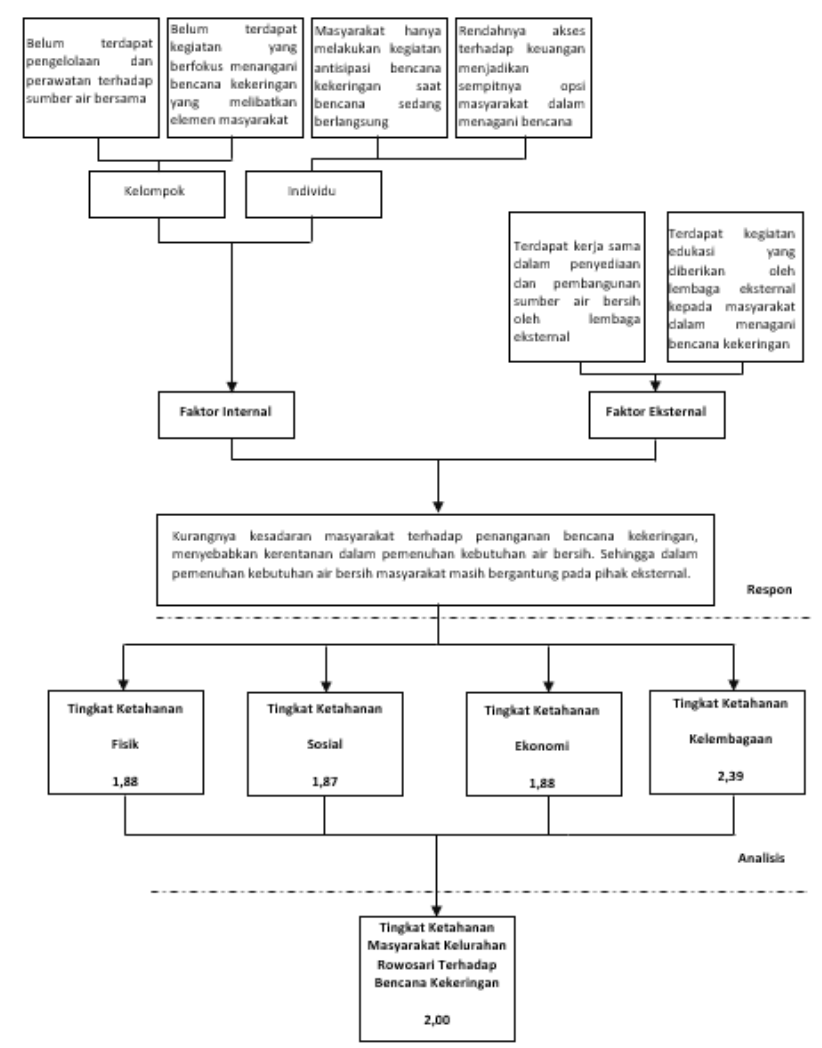

Gambar 3. Bagan Hasil Akhir Tingkat Ketahanan Masyarakat Kelurahan Rowosari Terhadap Kekeringan 


\section{KESIMPULAN}

Permasalahan bencana kekeringan yang terjadi di Kelurahan Rowosari dikarenakan kondisi wilayahnya yang rata-rata didominasi oleh daerah air tanah langka. Hal tersebut juga diperparah dengan seiring perubahan musim yang tidak menentu, seperti musim kemarau berkepanjangan. Bencana kekeringan yang terjadi di Kelurahan Rowosari tersebar di RW 01, RW 06 dan RW 09. Kondisi tersebut akhirnya mendorong masyarakat untuk mampu bertahan dalam menghadapi bencana kekeringan dengan modal yang dimiliki masing-masing masyarakat. Berdasarkan hasil penelitian ini, tingkat ketahanan masyarakat Kelurahan Rowosari terhadap bencana kekeringan secara keseluruhan berada dalam tingkat ketahanan menengah dengan skor akhir sebesar 2,00 . Perhitungan tersebut didapatkan melalui analisis perhitungan rata-rata skoring dari aspek fisik, aspek sosial, aspek ekonomi dan aspek kelembagaan.

Terdapat tiga aspek seperti aspek fisik, aspek sosial dan aspek ekonomi yang tergolong dalam kategori tingkat ketahanan menengah. Dalam aspek fisik, pada dasarnya lingkungan Kelurahan Rowosari sudah didukung infrastruktur yang baik untuk mendukung penanganan bencana kekeringan, namun untuk persebarannya belum merata. Selain didapatkannya hasil rendah pada beberapa indikator, untuk pengelolaan dan pemelihaaraan terkait infrastruktur masih sangat kurang diperhatikan oleh masyarakat dan pemangku kepentingan. Kondisi tersebut dibuktikan dengan sering matinya sumber air yang digunakan masyarakat baik sebelum dan sesudah bencana kekeringan.

Kemudian tergolongnya aspek sosial dalam tingkat ketahanan yang menengah sangat dipengaruhi oleh modal sosial yang terdapat dalam masyarakat. Dari kondisi tersebut dapat disimpulkan secara keseluruhan modal sosial yang dimiliki masyarakat Kelurahan Rowosari terhitung masih rentan. Untuk penanganan bencana kekeringan, masyarakat hanya mengandalkan bantuan dari lembaga terkait untuk penyediaan air bersih baik berupa dropping air bersih, pembangunan sumur artesis dan pembuatan toren penampungan air bersih. Kondisi tersebut juga sangat dipengaruhi oleh kondisi ekonomi masyarakat yang rata-rata berada dalam tingkatan menengah ke bawah. Dengan rendahnya akses masyarakat terhadap sumber keuangan menunjukan dalam hal ketahanan ekonomi, masih berada dikondisi yang tidak aman dalam mempersiapkan kebutuhan menghadapi bencana kekeringan dan dibutuhkan pihak eksternal dalam rangka penyelenggaraan kegiatan untuk mengatasi dan mengantisipasi bencana kekeringan.

Disisi lain terdapat satu aspek dengan kategori tingkat ketahanan tinggi seperti aspek kelembagaan. Tingkat ketahanan yang tergolong tinggi dalam aspek kelembagaan, menunjukan bahwa masyarakat Kelurahan Rowosari mampu mendapatkan peningkatan dalam hal pengetahuan dan menangani bencana kekeringan. Namun intensitas pelaksanaan terkait kegiatan edukasi yang diberikan oleh pihak eksternal dalam hal menanggulangi bencana kekeringan masih sangat minim. Sehingga setelah dilaksanakan kegiatan yang mengedukasi masyarakat kurang memberikan dampak yang berarti tanpa adanya implementasi dari kegiatan tersebut. Sehingga berdasarkan temuan penelitian yang didapatkan menunjukan bahwa gambaran tingkat ketahanan masyarakat dalam menghadapi bencana kekeringan di Kelurahan Rowosari sangat dipengaruhi oleh aspek-aspek yang erat dalam kehidupan bermasyarakat. Dengan saling bersinggungannya keempat aspek tersebut akan menunjukan seberapa baik tingkat ketahanan masyarakat dengan dikembangkan sesuai pada konteks tekanan dan guncangan yang dihadapi. Saling terkaitnya aspek yang digunakan dalam penelitian ini, dapat menunjukan karakteristik yang memberikan kontribusi dalam perencanaan lebih lanjut bagi pemangku kepentingan untuk dapat memprioritaskan tindakan-tindakan yang diperlukan untuk membangun dan meningkatkan nilai ketahanan masyarakat. Dari hasil penelitian ini, maka terdapat rekomendasi yang dapat diperhatikan untuk penelitian lanjutan seperti memperhatikan perhitungan neraca air yang terdapat di Kelurahan Rowosari dalam pengamatan bencana kekeringan dan diperlukan proyeksi dalam beberapa tahun ke depan untuk melihat kondisi bencana kekeringan agar dapat meningkatkan langkah-langkah penanggulangan 
bencana untuk mewujudkan ketahanan masyarakat yang berkelanjutan.

\section{DAFTAR PUSTAKA}

Adiwicaksono, H., Sudarto, S., \& Widianto, W. (2014). Estimasi Distribusi Spasial Kekeringan Lahan di Kabupaten Tuban Menggunakan Penginderaan Jauh dan Sistem Informasi Geografis. (JTSL) Jurnal Tanah dan Sumberdaya Lahan, 1(2), 73-78.

Bahadur, A. V., Ibrahim, M., \& Tanner, T. (2010). The Resilience Renaissance? Unpacking of Resilience for Tackling Climate Change and Disasters, Strengthening Climate Resilience Discussion Paper 1. Brighton: IDS.

Bappeda Kota Semarang. (2011). Peta Hidrogeologi Kota Semarang. Semarang: Bappeda Kota Semarang.

Bolte, P., Orlowsky, D. B., Marr, S., Moore, S., Rahmadana, M. F., \& Sitompul, D. (2017). Resilience Radar - User Manual Version 1.1, A Practical Tool to Measure Community Resilience. Australia: Banyaneer.

Kabir, M. H., Sato, M., Habbiba, U., \& Yousuf, T. B. (2018). Assessment of Urban Disaster Resilience in Dhaka North City Corporation (DNCC), Bangladesh. Procedia engineering, 212, 1107-1114. Doi: https://Doi.org/10.1016/j.proeng.2018.01. 143

Maguire, B., \& Hagan, P. (2007). Disasters and Communities: Understanding Social Resilience. Australian Journal of Emergency Management, 22(2), 16-20. Doi:

https://search.informit.com.au/document Summary; $\mathrm{dn}=839750155412061$;res=IELHS $S$

Mayunga, J. S. (2007). Understanding and Applying The Concept of Community Disaster Resilience: A Capital-Based Approach. Summer academy for social vulnerability and resilience building, 1(1), 1-16.

McMichael, A. J., Campbell-Lendrum, D. H., Corvalán, C. F., Ebi, K. L., Githeko, A., Scheraga, J. D., \& Woodward, A. (2003). Climate Change and Human Health: Risks and Responses. Malta: World Health Organization.

Prabowo, A. (2014). Kemarau Panjang, Tiga Daerah Ini Alami Kekeringan, Sindonews. Retrieved from

https://daerah.sindonews.com/berita/901 729/22/kemarau-panjang-tiga-daerah-inialami-kekeringan?showpage=all

Rangwala, L., Elias-trostmann, K., Wihanesta, R., Chandra, M., \& Org, W. R. I. (2018). Prepared Communities: Implementing the Urban Community Resilience Assessment in Vulnerable Neighborhoods of Three Cities: World Resource Institute.

Rigg, J., Salamanca, A., \& Parnwell, M. (2012). Joining The Dots of Agrarian Change in Asia: A 25 Year View from Thailand. World Development, 40(7), 1469-1481. Doi: https://Doi.org/10.1016/j.worlddev.2012.0 3.001

Sina, D., Chang-richards, A. Y., Wilkinson, S., \& Potangaroa, R. (2019). A Conceptual Framework for Measuring Livelihood Resilience: Relocation Experience from Aceh , Indonesia. World Development, 117, 253-265. Doi: https://Doi.org/10.1016/j.worlddev.2019.0 1.003

Sugiyono. (2012). Metode Penelitian Kuantitatif Kualitatif dan $R \& D$. Bandung: Alfabeta.

Thomas, T., Jaiswal, R., Galkate, R., \& Nayak, T. (2016). Reconnaissance Drought Index Based Evaluation of Meteorological Drought Characteristics in Bundelkhand. Procedia Technology, 24, 23-30. Doi: 10.1016/j.protcy.2016.05.005

UK Government. (2011). Climate Resilient Infrastructure: Preparing for a Changing Climate. TSO. 